\title{
EDWARD CHURTON AND HUGH JAMES ROSE: TWO VICTORIAN HISPANOPHILES
}

\author{
Martin Murphy \\ (Royal Historical Society) \\ martinhmurphy01@gmail.com
}

ABSTRACT: For some curiosos impertinentes of the Victorian era Spain offered a means of escape and self-discovery. Edward Churton, an Archdeacon and theologian, was a hispanist a distancia who fell in love with Spanish poetry and, in his remote Yorkshire rectory, wrote the first scholarly study of Góngora to be published in England. By contrast, Hugh James Rose, no intellectual, lived «among the Spanish people» (the title of one of his two books), first at Linares and later at Cadiz and Madrid, learning lessons in the art of living. His wide-ranging and sympathetic observations are of value to social historians.

KEYWORDS: Edward Churton, Hugh James Rose, hispanophilia, Góngora, Oxford University.

\section{EDWARD CHURTON Y HUGH JAMES ROSE: DOS HISPANÓFILOS VICTORIANOS}

RESUMEN: Para algunos «curiosos impertinentes» de la era victoriana, España proporcionó un medio de escape y de autodescubrimiento. Edward Churton, archidiácono y teólogo, fue un hispanista a distancia que se enamoró de la poesía española y, desde su remota rectoría en Yorkshire, escribió el primer estudio académico sobre Góngora que se publicó en Inglaterra. Por el contrario, Hugh James Rose no fue un intelectual, sino que vivió «entre el pueblo español» (el título de uno de sus dos libros), primero en Linares y después en Cádiz y Madrid, tomando lecciones del arte de vivir. Sus observaciones, empáticas y de amplios intereses, poseen valor para los historiadores sociales.

PALABRAS ClAVE: Edward Churton, Hugh James Rose, hispanofilia, Góngora, Universidad de Oxford.

There was no provision for the teaching of Spanish at Oxford till 1858, when Lorenzo Lucena, a native of Aguilar de la Frontera and a convert to Anglicanism, was appointed official instructor. His teaching duties committed him only to individual tuition of those who might want to acquire some Spanish for purposes of study or travel. His main occupation was the preparation of a new edition of the Reina-Valera bible for publication by the University Press.

Hispanists, then, at Oxford and elsewhere, were the product of accident rather than design. The principal function of early $19^{\text {th }}$ century Oxford was to produce clergymen for the Church of England, though — strange as it may seem — they followed a curriculum which consisted almost entirely of the pagan literature of Greece and Rome (along with some mathematics). Everything else - history, modern languages, English literature, music, the sciences, and even theology - was extracurricular. Richard Ford, who matriculated at Trinity College in 1813, justified the 
system (if it can be called a system) with an agricultural metaphor: «A good grounding in Greek and Latin, when patiently turned and trenched, forms the thick loam with which the mind of man is best fertilised».

Edward Churton, born in 1800, was just such a classical scholar, graduating from Christ Church in 1822. The son of an Archdeacon, he was predestined to become an Archdeacon himself. In 1835 he was appointed to the living of Crayke, in North Yorkshire - further north even than the Rectory of Patrick Bronte at Haworth. There he remained for over forty years as Rector of Crayke and Archdeacon of Cleveland (the North Riding of Yorkshire) until his death in 1874.

Like many hispanophiles, Churton's interest in Spanish literature was first kindled by reading Don Quixote, but he combined this romantic literary enthusiasm with a unique interest in Spanish theology and spirituality. He was the first to discover that a treatise attributed to the English theologian Jeremy Taylor was in fact a translation of Diferencia de lo temporal y eterno - a work by the Spanish Jesuit Juan Eusebio Nieremberg. In the learned monograph in which he proved his case he quoted from the works of Luis de León, Luis de Granada (praised for his «piety and good sense»), Melchior Cano, Francisco Suárez and Luis de Molina. ${ }^{1}$ He compared the treatment of Luis de León at the hands of the Inquisition in Salamanca to the condemnation of John Henry Newman by the University of Oxford in 1841. Nor was his interest in Spanish theology confined to the past. He was familiar with the contemporary work of Jaime Balmes and (especially) Felix Amat, the reforming Bishop of Astorga and translator of the Bible. He commissioned a portrait of Amat and contemplated writing his biography. «The Spanish know more about us than we about them», he observed. ${ }^{2}$

Simultaneously in his spare time and for his own amusement Churton was immersing himself in Golden Age literature, above all in the poetry of Góngora — not the Góngora of the Soledades («a long poem of this nature is too severe a trial of patience»), but the Góngora of the romances and sonnets, whom he admired for his «generous fire and quiet humour» as well as (on a deeper level) his «sense of moral beauty». Churton discovered Góngora for the English reader at a time when the poet was unknown in Britain, and when his reputation in Spain was at its lowest. His pioneer 2-volume work, Góngora: an historical and critical essay on the times of Philip III and IV of Spain, with translations (1862) was the first study of the poet and his milieu to appear in the English language, dedicated to Robert Southey and published by John Murray, the publisher of Richard Ford and George Borrow - not to mention Byron and Scott. The historical introduction is not only a colourful portrait of the age, based on a wide range of rare and curious source material, but a spirited defence of the poet against the charge of wilful obscurity and extravagance (he argued that critics had missed the self-mockery and burlesque implicit in the hyperbole).

The American Hispanist George Ticknor did not share Churton's admiration for Góngora - «nor do I think that his translations, though very free, and often better than the originals, will justify it», but he added: «I have read few books on Spanish literature and manners with so much pleasure». It might be more accurate to say that Churton reinvented Góngora's verse within the English ballad tradition, in a form acceptable to

\footnotetext{
${ }^{1}$ Edward Churton (1848), A letter to Joshua Watson Esq., giving an account of a singular literary fraud, London, Rivington.

${ }^{2}$ Pusey House, Oxford, Churton papers. Letters to W. Copeland, 30 September 1866, 2 May 1867.
} 
mid-Victorian taste. He himself preferred the term «metaphrase» to that of «translation», and certainly they are free versions, written rapidly at leisure. He belonged to the generation which had been brought up in childhood on the novels and «lays» of Walter Scott and on romantic versions of Spanish legend such as Lockhart's Ancient Spanish Ballads, Landor's Count Julian (1812) and Southey's Roderic: the last of the Goths (1814). He was most at ease when working within that genre, as in his version of a romance by Juan de Escobar (Appendix 1).

Churton's «metaphrases» of Gongora's sonnets and romances may usefully be compared with contemporary versions by John Dent-Young in his bilingual edition of selected poems (2007). Churton's Hermana Marica is quaint and sweet, reflecting the Victorian image of innocent childhood, whereas Dent-Young is more knowing. Again, Churton's version of the Flood of the Manzanares (Appendix 2) sacrifices the earthiness of the original to Victorian prudishness. His river has swollen not with a donkey's piss, but because washerwomen have emptied their pails in it. But the transformation of the washerwomen into nymphs is a conceit which might have pleased Góngora.

How did Churton manage to do all this in a remote Yorkshire rectory, without access to public libraries? The answer seems to be that he amassed a remarkable collection of his own (though what became of his Spanish books is as yet unknown). He also had access to two invaluable MSS. With the help of his friend and correspondent Pascual de Gayangos, the Arabist scholar and compiler of the catalogue of Spanish MSS in the British Museum, he obtained the loan of a 630-folio manuscript collection of Gongora's poems dating from about 1634, prefaced by personal reminiscences of the poet, now in the library of the Fundación Lázaro Galdiano. ${ }^{3}$ Churton himself owned an even more valuable manuscript, the Cancionero de Méndez Britto, dating from 1623 an anthology of poems by the Conde de Villamediana, Góngora, Lope de Vega, Antonio de Solís and Lupercio Leonardo de Argensola. This accounts for the inclusion in Churton's book of several poems by Villamediana - the first translations of his work to be published in English or indeed any other language. This cancionero, later acquired from Churton by Gayangos, is now in the Biblioteca Nacional (MS 17, 545), with a prefatory note by Gayangos: «Perteneció este ejemplar al Venerable Churton, arcediano de York, en Inglaterra, a quien conocí y traté». ${ }^{4}$ The frontispiece engraving of the Velázquez portrait of Góngora, then owned by Henry Reeve and now in Boston Fine Arts Museum, was commissioned by Churton himself.

Churton's passion for Spanish literature was not confined to the study. His daughter recalled how he adapted plays by Calderón and Pérez de Montalbán for his children to perform at holiday time. ${ }^{5}$ And he kept up with contemporary Spanish literature. In his opinion, Fernán Caballero was a better novelist than Jane Austen and «quite as good» as Charlotte M. Yonge. But he was a Hispanist a distancia. On his only expedition to Spain he got no further than the Basque country, being — as his daughter put it — «driven back by the heat». He had time nevertheless to do some local exploration which resulted in an article later published in the Proceedings of the York Architectural Society: «A Traveller's Notes on the Basque Churches».

The extraordinary breadth of Churton's literary interests is on show in his

\footnotetext{
${ }^{3}$ BN, MS Estrada 404. Dámaso Alonso, Estudios Gongorinos, Madrid, 1955, II, 259-62.

${ }^{4}$ Juan Manuel Rozas (1964), El Conde de Villamediana: Bibliografía y contribución al estudio de sus textos, Madrid, CSIC, p.7.

${ }^{5}$ Edward Churton (1876), Poetical Remains, ed. S.M. Inge, London.
} 
Poetical Remains, posthumously edited by his daughter. There are translations from Latin, Anglo-Saxon, Breton and Catalan as well as from the Spanish of Luis de León, Calderón, Vicent García de la Huerta, Tomás de Yriarte and Antonio de Trueba. His Spanish interests extended beyond literature to art, politics and history. The warmth of his private enthusiasm for all things Spanish was in sharp contrast to his public image. In his reminiscences of the Oxford Movement his younger contemporary Thomas Mozley wrote that there was «a coldness in his manner and expression that was almost chilling. He was too serious to smile; indeed I cannot remember him ever smiling, except sadly». Few if any of his contemporaries had any idea that beneath the high and dry exterior lay an ardent and tender romanticism. Spanish literature provided him with an elsewhere, far from the aridities of theological controversy.

A very different clergyman of the next generation - hispanófilo rather than hispanista - Hugh James Rose (1840-1878) — came, like Churton, from a long line of scholar parsons. His father was Archdeacon of Bedfordshire, and his paternal uncle another Hugh James Rose - was one of the founders of the Oxford Movement and later Principal of King's College, London. His maternal uncle, John William Burgon, a Fellow of Oriel and Vicar of St Mary's University church, was at Oxford for many years a formidable and indefatigable champion of lost causes and an enemy of change. Romanism, rationalism and liberalism were all anathema to him. He was against the admission to the university of nonconformists, Roman Catholics and (particularly) women. For a sermon preached in 1870, he took as his text a verse in the book of Genesis where God asks Jacob «Where is your wife?», to which Jacob answers «In the tent». That, argued Burgon, was where women belonged. The admission of women to university examinations in 1884 produced another blast from the pulpit, later published under the title To Educate Young Women like Young Men: A Thing Inexpedient and Immodest. He ended by addressing the female sex directly: «Inferior to us God made you, and inferior to the end you will remain. But you are none the worse off for that».

Hugh James Rose must have found the burden of family tradition heavy to bear, especially as his uncle was Dean of Oriel when he came up there as an undergraduate in 1860. Four years later he graduated with fourth class honours - not what was expected of a Rose. (A fourth was the class preferred by young aristocrats who regarded intellectual effort as «bad form» but it might also be the sign of a mind too wideranging and independent to be confined within the limits of the curriculum).

For seven years he served as a country curate and military chaplain, but his father's death in 1873 left him free to take a new direction. He accepted the post of chaplain to the English lead-mining company at Linares — off the beaten track, far from the tourist route. Most of the curiosos impertinentes who recorded their Spanish travels for the British reading public observed the passing scene at a distance, but Rose, during the four years he spent in Andalusia, studied the character and conditions of working people at close quarters.

Over a short period of twenty-four years Linares had experienced the development of a lead mining industry which by 1867 had become the largest in the world. During that time the population rose from 7000 to over 40,000 , and the landscape was transformed by the proliferation of engine houses and chimneys built to the design of similar buildings in Cornwall, the area from which skilled men were recruited for the Spanish mines. Rose found Linares to be a place without one particle of beauty: plomo. plomo, plomo wherever one looked. Most of the Cornish miners were Primitive Methodists whose language and thought were restricted to the bible. He preferred the jollier company of the Spanish miners and their families, investigating 
their work, pay and living conditions, diet, dress, amusements, customs, superstitions and herbal medicines. He went down the mine to witness the process of lead production and saw for himself its pollutant effect on the environment. Hence the title of his book: Untrodden Spain and her Black Country: being Sketches of the Life and Character of the Spaniard of the Interior. ${ }^{6}$

Rose's arrival in Málaga in September 1873 coincided with the last days of the cantonalist República Democrática Federal. Had he not been a clergyman, he would have been an excellent journalist. He found the city still controlled by the radical Intransigentes, who to his surprise turned out to be rather friendly. He had no doubt that the cantonalist cause was enthusiastically supported by the majority of the population, and saw how their hopes were dashed following the imposition of order (or «pacification») by General Pavía. His account of the fast-moving political crisis which culminated in the military coup of 3 January 1874 was remarkably unprejudiced. He recorded the rise and fall of the popular reputation of Castelar, hailed as a saviour on his accession to the Presidency on 6 September only to be vilified as an enemy of the people a few weeks later, when he brought in the army to disband the intransigentes. When he arrived in Málaga the sereno, on his nightly rounds, was still intoning ;Han dado las dos y media! ;Viva la República Democrática Federal! — but by the time he reached Linares the cry had reverted to the traditional ;Ave María purísima!

At Alora, on his way north, he saw a sight for which he was not prepared.

Walking out the next morning [after arrival] I heard in the distance the well-known strains of the Marsellaise played in the most lively manner by a brass band, and presently a tiny coffin, swung between four boys, came round the corner - the coffin of a little fair-haired child of some seven summers, laid out in blue paper, with a glass lid to show his peaceful face. A crowd of boys, cutting capers, singing and shouting, ran before it, while close behind, at a swinging pace, and playing their loudest and liveliest, came the band I had heard: behind them, four abreast, walked fifty or sixty young men, chiefly of the mining or artisan class. These deposited the coffin on the edge of the burial pit, and departed

For Rose, a man of deep, if unostentatious faith, the irreverence and disregard in this rural community for the Christian rites of passage were deeply disturbing. He noted with horror the poverty and neglect of the cemetery: little bodies of dead children wrapped in silver paper, the sandy soil littered with human bones, human hair clinging to the thistles, and «no tombstones worthy of the name». How had this come to be? He would give much thought to this question.

From the beginning Rose was determined not to let himself become the prisoner of his employers. The Spanish miners and their families were attracted by his good humour, simplicity and manly bearing. Above all he never proselytised - in fact was criticised by the Bible Societies for failing to do so. He and his wife learned much from their servants. The younger, Isidra, «a mischievous, hot-tempered, reckless little hoyden» fascinated him with her vivacious impudence and ready repartee. The elder, Isabel, lived in the house with her husband Manuel. Rose noted the intense devotion she lavished on her household god, a statue of the infant John the Baptist: «Every evening she would dress and undress San Juan, feel her saint's legs and make me feel them as I walked up to bed, all the while calling Pobre, pobre!»». One evening she stuck one of

${ }^{6}$ 1875, London, Samuel Tinsley, 2 vols. Spanish translation: Viaje a la Andalucía inexplorada (2012), Sevilla, Editorial Renacimiento. 
Rose's half-smoked cigars in the hand of the «little dressed-up doll», stationed at the foot of the marital bed, ready for Manuel to enjoy when he returned from work.

There was hardly any aspect of life at Linares, above or below ground which escaped his attention. He described all the processes of lead production and its effect on the environment, reporting the high rate of deaths from pleurisy, lead colic and consumption. The provision of medical care was rudimentary, and he found Dioscorides' Herbal (in the edition first published in 1695) still in use as the official pharmacopoeia. However, though the workers themselves were careless of their health and safety, he found that the government was quick to investigate the cause of accidents and to impose fines on foreign companies when they were at fault.

Other topics Rose covered include pay, diet, sports and leisure activities. For evening entertainment workers had the choice of the café (where they might play dominoes or enjoy the occasional zarzuela) or the brothel. At the ceremonies of Holy Week he was struck by the abrupt switch from raw passion to self-mockery, as when a group of boys sang «the wild, wailing chant of the Lenten ditty» only to break off abruptly with a shout of laughter.

After leaving Linares, Rose spent another year in Andalucía, as chaplain to the English speaking congregations in Jerez and Cádiz, which gave him the opportunity to travel more widely. His observations on charitable institutions give his work a documentary value which has yet to be fully appreciated by social historians. He was impressed by the Casa de Misericordia at Cádiz, where the inmates benefited from a combination of freedom and restraint, assistance and self-help. How much more humane, he thought, than the rigid, joyless system which prevailed in English workhouses! He was impressed too by the Escuela Normal: a teacher-training and model school combined where physical education and music were part of the syllabus, and trainees were instructed in the teaching of the deaf and dumb. But the republican government which had introduced this enlightened régime had also obliterated almost every trace of religion from public life: these institutions were deprived of chaplains, and at the Casa de los Niños Expósitos the rite of baptism had been discontinued. Only the Sisters of St Vincent de Paul continued to work in hospitals, orphanages and hospices, and Rose had nothing but praise for their dedication. How to account for the indifference, or even hatred for the Church? «My religion has broken down», an old boatman told him in Cádiz. The Church was no longer looked to for instruction, inspiration or support. It had lost its hold on the masses. Like an old officer trying to reassert his authority over a demoralised company of soldiers, it was simply ignored. Yet Rose sensed the unwritten, unspoken Christianity that lay beneath the surface: what an Irish poet called «the secret scriptures of the poor».

In a second book, Among the Spanish People (1877), he covered a variety of further topics: nursery rhymes, dance, superstitions, fairs, rustic theatre, and the new fashion among the upper class for English sports such as horse-racing, rowing and even cricket. He himself felt more at home in the world of the barrios bajos. He wrote that being poor, he frequently had to travel on foot, and to eat and sleep with them, finding among the Spanish peasantry "what he had sought but not hitherto found: truth, brotherly kindness, chivalrous devotion, nobleness of character, religion without cant and every virtue mixed with a little dirt».

In addition he reported for the London Times on social improvements, reflecting his increasing interest in prison reform. In the course of his investigations he found much that the British could learn from. Solitary confinement was unknown, and in the presidio at Cartagena all who had a trade were allowed to work at it, and to teach those 
who had none. How different from the so-called «model» gaol at Oxford, where prisoners were put to the merely punitive exercise of the treadmill! At the women's gaol in Alcalá mothers were allowed to have their children with them, and he was touched by the solidarity of the inmates: since he had insufficient money to give to each, the haves shared their alms with the have-nots. "Where in the "religious world" would you find a self-sacrifice to equal that?». He paid tribute to the republican government for its reforms, but at the same time painted a horrifying picture of the conditions he found in the dungeons of the Saladero in Madrid and the Hacho at Ceuta:

Oh the eager staring eyes, the open mouths, the outstretched dirty hands, the trembling, pointing fingers, those black, guilt-hardened animal faces, those eyes staring with hunger, wolfish in their glaring eagerness, I shall never forget! Language fails to paint the darkness, the filth, the seething corruption of these dens into which no speck of sunlight, divine or human, ever finds a way, and where nothing is heard or seen but assassination and cruelty on the one hand; misery, starvation and obscenity on the other!

This interest in the lower depths of society, he protested, was not prompted by «motives of prurient curiosity», but by a wish «to do good to a country to which I have become attached, and to whose inhabitants I owe a debt of sincere gratitude». It is typical of him that on his visit to Madrid he headed, not for the Prado but for the washing grounds on the banks of the Manzanares, to seek out the laundresses (Churton's nymphs), to enquire into and note down their pay and conditions. Among the Spanish People has a whole chapter devoted to these «toilers of the river», including the prices they charged. A policeman, asked by him how many lavanderas there were (well over 10,000 in fact), replied «As many saints as there are in heaven».

No Englishman was more susceptible than Rose to the attractions of what he called «the Spanish Woman», on which subject he outdid Don Quixote himself. In a passage on «the outward charms of the woman of the lower class» he wrote:

Her form is perfectly symmetrical, and not an ounce of flesh is out of place ... Her eyes are dark, lustrous and vagrant, sometimes wandering hither and thither with a rapt, unconscious gaze, as though in perpetual quest of the something that can never be found ... Her breasts are fully developed, pointed and conical; hands delicately small and well-shaped; chin square, short and pointed, as the chins of ladies on old English brasses [...] She is the picture of rude health; can eat a garlic stew at six in the morning; hoe in the field; bear children without doctor's assistance, and be at market two days afterwards.

He admitted, however, that «the Spanish beauty generally fails in her nose and mouth», adding that her character varies according to zone: «The farther you go north, the kinder and better are the women. Graceful and kindly as they are, the Andalusian women have not the depth and truth of the Castilians or Cataluñans». Madrid, however, was «the curse of Spain» - a place where «men have no mercy, no pity, no bowels of compassion for women». In a chapter entitled «Low Madrid» he described how in the gipsy quarter below the Toledo bridge - what he called the barrio de las injurias $y$ cambroneras - he found the true nobleness of character he had long been searching for: "To have known a common gypsy woman in all her height of purity and depth of devotion; in all her self-denial; in all her religion, without religion's offensive savour, is a liberal education». An education evidently more liberal than the one he had received at Oxford University. 
In December 1874 he reported the entry into Madrid of the troops who came to restore the monarchy. It was good, he thought, for the cheering crowds to see these battle-hardened men in threadbare uniforms, «with their war-worn, reckless, dare-devil faces and their broken sandals, that they may learn to know that war is not a jest». These soldiers, he added prophetically, would probably help to create a military despotism, «but, naturally intelligent, they have their questions to ask, and will one day require an answer».

In a concluding chapter Rose praised the social and educational improvements that took place between 1875 and 1877, singling out the inauguration of the Institución Libre de Enseñanza — «a gallant, a noble, a praiseworthy effort to shake off the trammels of State control and Church supervision», but in general he took a gloomy view of the country's prospects under a revived monarchy: «Seville has returned to the Middle Ages», a correspondent there told him: «Priests, bandits, bullfighters and Bourbons are once more flourishing».

By the end of 1876 Rose was a sick man. He returned to England, where he died two years later, aged only 37 , leaving a widow and two children. He is buried in the churchyard of Houghton Conquest, but he left something of himself where he had found liberation, in Spain.

\section{APPENDIX 1: JUAN DE ESCOBAR, QUANTOS DICEN MAL DEL CID}

Base tongues that rail against the $\mathrm{Cid}$ Shall spend their spite in vain:

For the Cid was a noble gentleman

And the best good lance of Spain.

True servant to his King he was, And the champion of his land, A foe to traitors - to true men

He gave both heart and hand

And in his life and in his death

Did earn immortal praise

Whate'er ill-tempered rhymers say

In these unfaithful days.
Quantos dizen mal del Cid, ninguno con verdad habla que el Cid fue buen caballero Y el mas valiente de España

gran servidor de sus Reyes, gran defensor de su patria, enemigo de traydores $\mathrm{y}$ amigo de gente honrada:

el que en la vida y la muerte mereció digna alabanca, aunque malvados poetas Se atreven y desacatan.

For the complete text (Romance LXXXIII), see A. Rodríguez-Moñino (ed.) (1973), Historia y romancero del Cid, Madrid, Castalia, pp. 228-229.

\section{APPENDIX 2: THE BRIDGE OF SEGOVIA}

Churton:

Have mercy, Manzanares! Out, alas!

Have mercy on that bridge! For, people say, A bridge so wide might let the gulf-stream pass 
While half an arch might give thy current way.

How proudly swol'n comes down thy watery mass,

Which late, as in the Dog-Days, lowly lay!

Now, in the name of him whose scheme it was

To scour the town with chicory, and convey

The drench to thee - why this unusual height?

Why this amazing change to bliss from bale,

Why now in glory, then in penal pain?

Well, if you'll keep the secret, yesternight

The laundry-nymphs upstream each fill'd her pail,

Today they've thrown the soap-suds out again. 